\title{
Elaboration of biscuits with oatmeal and fat palm with added L-leucine and calcium for sarcopenia
}

Telma Elita BERTOLIN ${ }^{1 *}$, Andressa CENTENARO ${ }^{1}$, Bruna GIACOMELLI ${ }^{1}$, Christian REINEHR ${ }^{1}$, Luiz Carlos GUTKOSKI ${ }^{1}$

\begin{abstract}
The objective of this study was to evaluate the effect of the addition of oatmeal and palm fat in the elaboration of biscuits with added L-leucine and calcium in order to develop a product for sarcopenia in the elderly. The biscuits, or cookies, were elaborated applying a central composite rotational design with surface response methodology, and the significant linear, quadratic and interaction terms were used in the second order mathematical model. Physical, physicochemical and sensory analyses were performed by a trained panel. Based on the best results obtained, three cookie formulations were selected for sensory evaluation by the target group and physicochemical determinations. The formulations with the highest sensory scores for appearance and texture and medium scores for color and expansion index were selected. The addition of calcium and leucine increased significantly the concentration of these components in the biscuits elaborated resulting in a cookie with more than $30 \%$ of DRI (Dietary Reference Intake) for calcium and leucine. The formulations selected showed high acceptance by the target group; therefore, they can be included in the diet of elderly with sarcopenia as a functional food.
\end{abstract}

Keywords: Avena sativa; aging; muscle loss.

\section{Introduction}

The world population has become older, and it is estimated that a world demographic change happens within the next 50 years since the number of elderly in 2000 was 600 million and it will reach nearly 1 billion and 200 thousand in 2050 (SILVA et al., 2006, GARCIA; SAINTRAIN, 2009). Population aging and longevity increase have led to an increase in the absolute and relative numbers of older people (ALVES; LEITE; MACHADO, 2008).

A physiological change in elderly population that has gained importance is the gradual loss of muscle tissue and strength that normally accompanies aging. According to Wenz et al. (2009), this phenomenon is known as "sarcopenia".

Muscle mass is reduced by approximately one-third between the ages of 50 and 80 as a part of normal cause of aging, and the complications resulting from falls are the sixth leading cause of death in people over 65 (BORST, 2004). Rieu et al. (2006) state that the maintenance of the muscle strength and prevention of sarcopenia are important for the elderly, focusing on their personal independence.

The branched chain amino acids interfere in the metabolic regulation of the muscle protein synthesis and, among them, leucine acts as a positive mediator of protein synthesis (DARDEVET et al., 2003, ZANCHI; NICASTRO; LANCHA JUNIOR, 2008). The predominant effect of leucine on the metabolic regulation of the muscle protein synthesis indicates that leucine stimulates the synthesis and inhibits protein degradability (NAIR; SCHWARTZ; WELLE,
1992, DARDEVET et al., 2002, VENTRUCCI et al., 2004, COMBARET et al., 2005; RIEU et al., 2007).

Calcium is an essential mineral for the muscle function. It is stored in the sarcoplasmatic reticulum and released when the muscle fibers are stimulated. Adequate calcium consumption is important for health. When there is not enough of its consumption, calcium is removed from its local of storage in the body, mainly from the bones (WILMORE; COSTILL, 2001; BUCCI et al., 2005). Deficient or inadequate calcium absorption may cause changes in the response to stimuli received from muscle fibers

There is a growing concern in society about the interaction between nourishment and health. Consumers are increasingly opting for healthier food which can bring some additional benefits than those offered by traditionally commercialized products (BELLO, 1995; ZIEGLER; SGARBIERI, 2009).

Functional diet is beverages and foods that may bring specific physiological benefits when daily consumed due to the presence of healthy physiological ingredients (CANDIDO; CAMPOS, 2005).

In the context of healthy diet, oat, which is a functional food, has received great attention by doctors, nutritionists, consumers, and regulatory agencies due to its nutritional characteristics and mainly due to the content and quality of its fibers (GUTKOSKI et al., 2007). Furthermore, trans fatty acids (TFA) have been included among the dietary lipids which act as risk factors for coronary artery disease (LICHTENSTEIN,

${ }^{1}$ Curso de Engenharia de Alimentos, Laboratório de Fermentação, Universidade de Passo Fundo - UPF, BR 285, Km 171, São José, CEP 99001-970, Passo Fundo, RS, Brazil, e-mail:telma@upf.br

${ }^{*}$ Corresponding author 
1993), making it interesting to replace the hydrogenated fat with fat free from TFA such as palm fat (LIST, 2004). A biscuit using oat and palm fat with the addition of L-leucine and calcium was elaborated to prevent sarcopenia in the elderly.

\section{Materials and methods}

Wheat flour, palm fat, and oat were provided by mill CBM, company Prozyn Bio Solutions, and Saboreal, respectively. Leucine was provided by company Ajinomoto Interamericana Indústria e Comércio Ltda, and calcium phosphate was acquired from Synth (São Paulo - Brazil). The other raw materials needed for the production of the biscuits were acquired from local stores.

\subsection{Obtaining the biscuits}

The base formulation of the biscuits (standard) followed the AACC 10-50D method (AMERICAN..., 1995), with adaptations according to Gutkoski et al. (2007), using 225,5 g wheat flour (49,6\%), $115 \mathrm{~g}$ de sugar $(25,3 \%), 2,1 \mathrm{~g}$ salt $(0,4 \%)$, $60 \mathrm{~g}$ hydrogenated vegetable fat (13,2\%), $4 \mathrm{~g}$ baking powder $(0,9 \%), 15,5 \mathrm{~mL}$ distilled water $(3,4 \%)$, and $32,8 \mathrm{~mL}$ dextrose solution at $5,93 \%(7,2 \%)$.

Hydrogenated vegetable fat was replaced with palm fat, and the amount of fat to be added to each formulation was calculated based on the total mass of the base formulation. Sugar was sieved through a 30-mesh sieve. The wheat flour of the base formulation was partially replaced with oat according to the concentration of oat in each treatment. The oat used was composed of $50 \%$ oat meal and $50 \%$ oat flakes. The oatmeal flakes differ from the oat meal flour by their larger grain size (GUTKOSKI et al., 2009). The mixture of flakes and oatmeal flour was used to provide a gradient of particle size seeking to better texture.

Fat, sugar, and salt were mixed using an electrical Kitchen Aid mixer at low speed for three minutes pausing every minute to scrape down the sides of the recipient. Next, in the same recipient, the distilled water and the dextrose solution were added and mixed at low speed for a minute, initially, and again for one more minute at average speed. After that, the flour, oat, baking powder, L-leucine and calcium were added, and the dough was mixed at average speed for two minutes, stopping at every 30 seconds to scrape down the sides of the recipient. The dough was divided into servings, rolled to a thickness 13 of $\mathrm{mm}$, and cut using stainless steel cutter (60 $\mathrm{mm}$ diameter). The dough discs of uniform circumference were weighed and baked at $204^{\circ} \mathrm{C}$ for 14 minutes in an experimental model oven QA 226 (Labor Instruments Works, Hungria).

Six units of biscuits, which were stored in hermetically closed recipient one hour after being taken out from the oven, were elaborated.

The quantity of L-leucine and calcium added was based on $100 \mathrm{~g}$ of the final product, and it accounted for 30\% of Dietary Reference Intake (DRI) for people older than 51 years old (INSTITUTE..., 1997, 2005). These ingredients were added to the dough together with the flour.
All formulations elaborated were submitted to physical and sensory analysis by a trained panel to select the three best formulations.

Central composite rotational design with surface response methodology (BOX; DRAPER, 1987) was applied to study the effect of combined variables of oat and palm fat on the formulation of the cookies.

The variables were set at five coded levels in which $\alpha=1.414$ and the significant linear, quadratic, and interaction terms were used in the second order mathematical model. Eleven treatments were used in the design: four factorial (combination of -1 and +1 levels), four axial (one variable at $\pm \alpha$ levels and the other at zero), and three central designs (both variables at zero). The real and encoded values of the experimental composite rotational design of both independent variables and five levels of variation are shown in Table 1.

\subsection{Physical evaluation}

The physical analysis included mass loss expansion index, specific volume, and color, according to the AACC method (AMERICAN..., 1995), which, except for the mass loss, was performed in triplicate 24 hours after biscuits' elaboration.

The mass loss of the biscuits was determined by the mass variation, before and after cooking. The mass of the biscuits after cooking was determined one hour after they were taken out of the oven. The biscuits diameter and thickness were determined using a digital paquimeter. The expansion index was obtained by the ratio between the values of the diameter and thickness of the biscuits, corrected by altitude and atmospheric pressure at sea level, according to the AACC table (AMERICAN..., 1995). The color of the biscuits was determined by the use of diffuse reflectance spectroscopy using a ColorQuest II Sphere spectrophotometer (Hunter Associates Laboratory, Inc. Reston, EUA) equipped with an optical sensor.

\subsection{Sensory evaluation by trained panel}

The sensory analysis was performed by three trained panelists 5 to 7 days after the biscuits production. The parameters

Table 1. Encoded and real levels of variables of the central composite rotational design used for the development of biscuits for the elderly with sarcopenia.

\begin{tabular}{lcccc}
\hline Formulation & $\mathrm{X}_{1}$ & $\mathrm{X}_{2}$ & Oat $(\%)$ & Palm fat (\%) \\
\hline A9G8 & -1 & -1 & 9 & 8 \\
A51G8 & 1 & -1 & 51 & 8 \\
A9G22 & -1 & 1 & 9 & 22 \\
A51G22 & 1 & 1 & 51 & 22 \\
A0G15 & $-a$ & 0 & 0 & 15 \\
A60G15 & $+a$ & 0 & 60 & 15 \\
A30G5 & 0 & $-a$ & 30 & 5 \\
A30G25 & 0 & $+a$ & 30 & 25 \\
A30G15 & 0 & 0 & 30 & 15 \\
A30G15 & 0 & 0 & 30 & 15 \\
A30G15 & 0 & 0 & 30 & 15 \\
\hline
\end{tabular}

$a=1.414$ for $\mathrm{K}=2$ (two independent variables). $\mathrm{X}_{1}=$ Oat and $\mathrm{X}_{2}=$ Palm fat. 
scored were general appearance, smell, texture, and taste, using a maximum value of 9 points for each sensory attribute according to the methodology proposed by Gutkoski et al. (2007).

The three formulations selected from the results of the physical analysis and from the scores obtained were produced in enough amount to undergo physicochemical analysis and sensory affective tests with the target group.

\subsection{Physicochemical analysis}

Humidity, gross protein, lipids, and ash were determined according to the AOAC methods (AMERICAN..., 2005). Carbohydrates were calculated by difference according to the RDC no 360 (BRASIL, 2003) for the caloric value calculation. The analyses were performed in duplicate and the results expressed in percentage.

Calcium determination was achieved according to the method of Atomic Absorption Spectrometry (ELMER, 1982). In addition to the three formulations selected, the concentration of calcium was quantified based on the biscuit base formulation, proposed by AACC (AMERICAN..., 1995), in order to compare the results.

The amino acid L-leucine quantification was performed by ion-exchange chromatography with post-chromatographic derivatization by ninhydrin, according to the method proposed by Spackman, Stein and Moore (1958) using an automatic analyzer (ALONSO; HIRS, 1968), in which the samples were previously hydrolyzed with $\mathrm{HCl} 6$ mol. $\mathrm{L}^{-1}$ for 22 hours. The concentration of L-leucine in the base formulation and in the formulation of the central point (A30G15) was determined. The same amount of L-leucine was added to all formulations, except for the base formulation (without addition). L-leucine was quantified only in the central point formulation since it represents the other formulations.

To identify trans fatty acids in the cookies, the fatty acid quantification was performed using the Ce 1 f-96 method (AMERICAN..., 2002).

\subsection{Sensory evaluation performed by the target group}

The three formulations selected were evaluated by the affective test according to the method proposed by Faria and
Yotsuyanagi (2002). The biscuits samples were evaluated after 12 days of elaboration by a team of 30 untrained judges, who attend CREATI (Regional Center of Studies and Activities for Elderly) in the city of Passo Fundo (male or female aged over 60 years) and represent the target group. This sensory evaluation was submitted and approved by the Ethics Committee of Passo Fundo University (approval \# 0121.0.398.000-09). The samples were offered to the judges at room temperature in recipients coded with three-digit numbers. The analysis was performed under daylight equivalent white light. A hedonic scale ranging from "I disliked very much (1) to I liked very much (5)" was used to evaluate appearance, color, smell, taste, and texture. Total acceptance of the biscuits was calculated based on these characteristics.

\subsection{Statistical analysis}

The averages of the results of the physical analyses and sensory analysis performed by trained panel were treated by multiple regression analysis to verify the possibility of describing the effects of the independent variables using mathematical models and performing response surface analysis.

The level of significance of the regression was tested using the F-test and the determination coefficient (BARROS NETO; SCARMINIO; BRUNS, 1995) in the models adapted.

The results of the acceptance test and the physicochemical analyses were submitted to the analysis of variance (ANOVA) and, in the significant models, the means were compared by the Tukey test at $5 \%$ significance level $(\mathrm{p}<0,05)$.

\section{Results and discussion}

\subsection{Physical and sensory evaluation performed by a trained panel}

Table 2 shows the results of the physical and sensory analyses performed by a trained panel for the biscuits formulations developed.

The regression mathematical models that show the relationship between the conditions used and the values obtained in the analyses were developed using the data obtained

Table 2. Results of mass loss (ML), specific volume (SV), mean expansion index (MEI), lighting $\left(\mathrm{L}^{\star}\right)$, red intensity $\left(\mathrm{a}^{\star}\right)$, general appearance $(\mathrm{GA})$, odor $(\mathrm{O})$, texture $(\mathrm{T})$, and taste $(\mathrm{TA})$ of the formulations elaborated.

\begin{tabular}{|c|c|c|c|c|c|c|c|c|c|}
\hline Formulation & ML (\%) & $\mathrm{SV}(\mathrm{mL} / \mathrm{g})$ & $\operatorname{MEF}(\mathrm{d} / \mathrm{e})$ & $\mathrm{L}^{*}$ & $a^{*}$ & GA & $\mathrm{O}$ & $\mathrm{T}$ & TA \\
\hline A9G8 & $1.49 \pm 0.05$ & $.62 \pm 0.01$ & $.06 \pm 0.02$ & $76.77 \pm 0.22$ & $1.48 \pm 0.02$ & $4.83 \pm 0.71$ & $7.67 \pm 0.47$ & $5.50 \pm 0.24$ & $5.17 \pm 0.24$ \\
\hline A51G8 & $12.31 \pm 0.06$ & $.80 \pm 0.02$ & $30 \pm 0.01$ & $66.59 \pm 0.15$ & $.30 \pm 0.38$ & $67 \pm 0.01$ & $4.50 \pm 0.24$ & $.67 \pm 0.47$ & $3.83 \pm 0.24$ \\
\hline A9G22 & $12.25 \pm 0.26$ & $1.48 \pm 0.04$ & $1.51 \pm 0.01$ & $72.30 \pm 0.47$ & $2.56 \pm 0.03$ & $8.00 \pm 0.47$ & $8.67 \pm 0.47$ & $8.50 \pm 0.71$ & $8.83 \pm 0.24$ \\
\hline A51G22 & $7.86 \pm 0.02$ & $.83 \pm 0.01$ & $2.46 \pm 0.01$ & $57.52 \pm 0.35$ & $8.09 \pm 0.06$ & $2.50 \pm 0.24$ & $4.33 \pm 0.47$ & $4.17 \pm 0.24$ & $5.17 \pm 0.71$ \\
\hline A0G15 & $10.97 \pm 0.07$ & $1.54 \pm 0.01$ & $1.11 \pm 0.01$ & $77.15 \pm 0.28$ & $2.17 \pm 0.12$ & $4.17 \pm 0.24$ & $5.83 \pm 0.71$ & $5.50 \pm 0.24$ & $5.33 \pm 0.47$ \\
\hline A60G15 & $12.21 \pm 0.13$ & $1.85 \pm 0.02$ & $1.96 \pm 0.01$ & & & & & & \\
\hline A0G5 & $11.54 \pm 0.07$ & $1.63 \pm 0.01$ & $1.04 \pm 0.02$ & $61.07 \pm 0.54$ & $6.48 \pm 0.28$ & $4.00 \pm 0.94$ & $5.67 \pm 0.01$ & $3.50 \pm 0.24$ & $7.50 \pm 0.24$ \\
\hline A60G25 & $13.14 \pm 0.27$ & $1.75 \pm 0.01$ & $2.10 \pm 0.03$ & $63.26 \pm 1.03$ & $6.83 \pm 0.76$ & $5.33 \pm 0.47$ & $2.50 \pm 0.24$ & $8.50 \pm 0.71$ & $6.17 \pm 0.24$ \\
\hline A30G15 & $12.64 \pm 0.35$ & $1.55 \pm 0.01$ & $1.45 \pm 0.02$ & & & & $8.50 \pm 0.24$ & $8.67 \pm 0.47$ & $7.67 \pm 0.01$ \\
\hline A30G15 & $12.46 \pm 0.10$ & $1.54 \pm 0.02$ & $1.49 \pm 0.01$ & $67.65 \pm 0.06$ & $5.35 \pm 0.02$ & $8.33 \pm 0.47$ & $8.17 \pm 0.24$ & $8.50 \pm 0.71$ & $7.83 \pm 0.24$ \\
\hline A30G15 & $12.48 \pm 0.14$ & $1.59 \pm 0.03$ & $1.47 \pm 0.01$ & $66.49 \pm 0.03$ & $5.19 \pm 0.04$ & $8.50 \pm 0.71$ & $8.33 \pm 0.47$ & $8.83 \pm 0.24$ & $7.67 \pm 0.47$ \\
\hline
\end{tabular}


in physical and sensory analyses performed by a trained panel. Table 3 shows the analysis of variance of the regressions, determination coefficient $\left(\mathrm{R}^{2}\right)$, the adapted models of physical and sensory analysis for the biscuits formulations developed

According to Muralidhar et al. (2001), the F value calculated must be higher than the tabulated $\mathrm{F}$ in order to reject the null hypothesis at the studied significance level, which implies that the variation caused by the model is significantly higher than the variation that was not explained. Apart from the value of $\mathrm{F}$, the determination coefficient $\left(\mathrm{R}^{2}\right)$ was used to check the model quality and the value of $\mathrm{R}^{2}$ obtained, which indicates the perceptual that the response variability is explained by the model. In Table 3, it can be seen that the responses of the variables Mass loss (ML) and odor $(\mathrm{O})$ had F values very close to the tabulated values and $\mathrm{R}^{2}$ less than 0.8 , indicating that no regression model of these variable responses will be obtained. Table 4 shows equations as regression models of the physical and sensory analyses of the biscuit formulations developed.

The analysis of the regression models shows that the percentage of oat and palm fat influenced significantly the characteristics of specific volume of the biscuits according to Table 3. The specific volume may be affected by several factors, such as the quality of the ingredients used in the dough formulation, especially flour; moreover, the specific volume is affected by treatments during the processing (EL-DASH; CAMARGO, 1982). The values of specific volume obtained ranged from $1.48 \mathrm{~mL} \cdot \mathrm{g}^{-1}$ (A9G22) to $1.85 \mathrm{~mL} \cdot \mathrm{g}^{-1}$ (A60G15); and they are lower in the formulation with less quantity of oat. Bath, Shelke and Hoseney (1992) verified that the retention of air and gas fermentation influence the mass density and viscosity.

The expansion index of the biscuits is calculated by the ratio between the diameter and thickness $(\mathrm{d} / \mathrm{t})$, and these parameters are used to predict the quality of the products. The diameter of the biscuits ranged from $69.605 \mathrm{~mm}$ (A0G15) to $96.463 \mathrm{~mm}$ (A51G22); thickness ranged from $7.93 \mathrm{~mm}$ (A51GP22) to $13.93 \mathrm{~mm}$ (A0G5) and the expansion index from 1.03 (A0G5) to 2.46 (A51G22). Figure 1 shows the response surface plot obtained for the effect of addition of oat and palm fat on the expansion index of the biscuits.
Table 4 shows that the quadratic and linear effects of palm fat and oat had significance $(\mathrm{p}<0.05)$ with respect to the expansion index of the biscuits elaborated. The use of high concentrations of oat and the high concentrations of palm fat provided greater expansion index.

The oat used acted as diluent of wheat flour gluten causing reduction in the flour strength $\left(\mathrm{W} \times 10^{-4} \mathrm{~J}\right)$ and was responsible for the highest values of the expansion index found in the formulations with high oat concentration. It was observed that the formulations A51G22; A60G15, and A60G25 had expansion index greater than $2.0(\mathrm{~d} / \mathrm{t})$, while values below $1.5(\mathrm{~d} / \mathrm{t})$ were found in the formulations A9G8; A0G15, and A0G5, as shown in Table 2. Gutkoski et al. (2007) found that the expansion index of biscuits increased proportionally with the addition of oat flakes. Rasco et al. (1990) found variable effects of different materials rich in fibers on the expansion index of biscuits. These authors reported that the expansion of biscuits prepared with barley grains was higher than that of the control biscuits.

Some studies suggest that the fat substitutes could contribute to the elastic net formation that causes mass retraction after cooking, eventually showing less expansion in biscuits (ZOULIAS; OREOPOULOU; TZIA, 2002). With regards to the results obtained in the present study, the expansion index of the formulations A0G5, A51G8, and A9G8 had $1.04(\mathrm{~d} / \mathrm{t})$, $1.30(\mathrm{~d} / \mathrm{t})$, and $1.06(\mathrm{~d} / \mathrm{t})$, respectively, showing that the decrease in fat concentration resulted in biscuits with lower expansion index, demonstrating that greater elastic net formation might have occurred. Lee and Inglett (2006) replaced part of the biscuit fat with oat bran, and which led to a significant decrease in the biscuits diameter $(\mathrm{p}<0.01)$, and therefore the control treatment showed higher growth rate.

Matz (1968 apud SILVA; SILVA; CHANG, 1998), argues that the biscuits with very high or very low expansion index cause problems to the industry resulting in very high weight or small-sized products.

The sensory characteristics of taste were influenced significantly by different percentages of oat and palm fat addition, as shown in Table 3. According to Zoulias, Oreopoulou and Tzia (2002), fat influences positively the taste and smell

Table 3. Significance levels of the effects (p), F value, and the coefficient of determination of the statistical models developed to evaluate the influence of the addition of oat $\left(\mathrm{X}_{1}\right)$ and palm fat $\left(\mathrm{X}_{2}\right)$ concentrations on the mass loss $(\mathrm{ML})$, specific volume (SV), mean expansion index (MEI), lighting $\left(\mathrm{L}^{*}\right)$ and red intensity $\left(\mathrm{a}^{*}\right)$, general appearance $(\mathrm{GA})$, odor $(\mathrm{O})$, texture $(\mathrm{T})$ and taste $(\mathrm{TA})$ of the formulations elaborated.

\begin{tabular}{|c|c|c|c|c|c|c|c|}
\hline & \multicolumn{5}{|c|}{ Probability (p) } & \multicolumn{2}{|c|}{ Analysis of variance } \\
\hline & $\mathrm{X}_{1}$ & $\mathrm{X}_{1}^{2}$ & $\mathrm{X}_{2}$ & $\mathrm{X}_{2}^{2}$ & $\mathrm{X}_{1} \cdot \mathrm{X}_{2}$ & F calculated & $\mathrm{R}^{2}$ \\
\hline $\mathrm{ML}$ & 0.4343 & 0.0481 & 0.5330 & 0.3237 & 0.0047 & 3.3081 & 0.5083 \\
\hline MEI & 0.0000 & 0.0001 & 0.0000 & 0.0000 & 0.0000 & 1212.8382 & 0.9974 \\
\hline SV & 0.0000 & 0.0001 & 0.5133 & 0.0002 & 0.0122 & 33.8343 & 0.9136 \\
\hline $\mathrm{L}^{*}$ & 0.0000 & 0.3948 & 0.1001 & 0.1433 & 0.2942 & 18.7078 & 0.8539 \\
\hline$a^{*}$ & 0.0000 & 0.7355 & 0.0565 & 0.3034 & 0.2743 & 18.2718 & 0.8510 \\
\hline GA & 0.9090 & 0.0001 & 0.6155 & 0.0001 & 0.0000 & 15.0647 & 0.8248 \\
\hline $\mathrm{O}$ & 0.0064 & 0.0194 & 0.1949 & 0.0005 & 0.5489 & 6.5948 & 0.6733 \\
\hline $\mathrm{T}$ & 0.0002 & 0.0000 & 0.0000 & 0.0001 & 0.0068 & 28.3407 & 0.8985 \\
\hline TA & 0.1459 & 0.0001 & 0.2827 & 0.6960 & 0.0000 & 13.8501 & 0.8123 \\
\hline
\end{tabular}

$\mathrm{F}$ tabled $=2.8524 ; \mathrm{X}_{1}=$ Oat; $\mathrm{X}_{2}=$ Palm fat. 


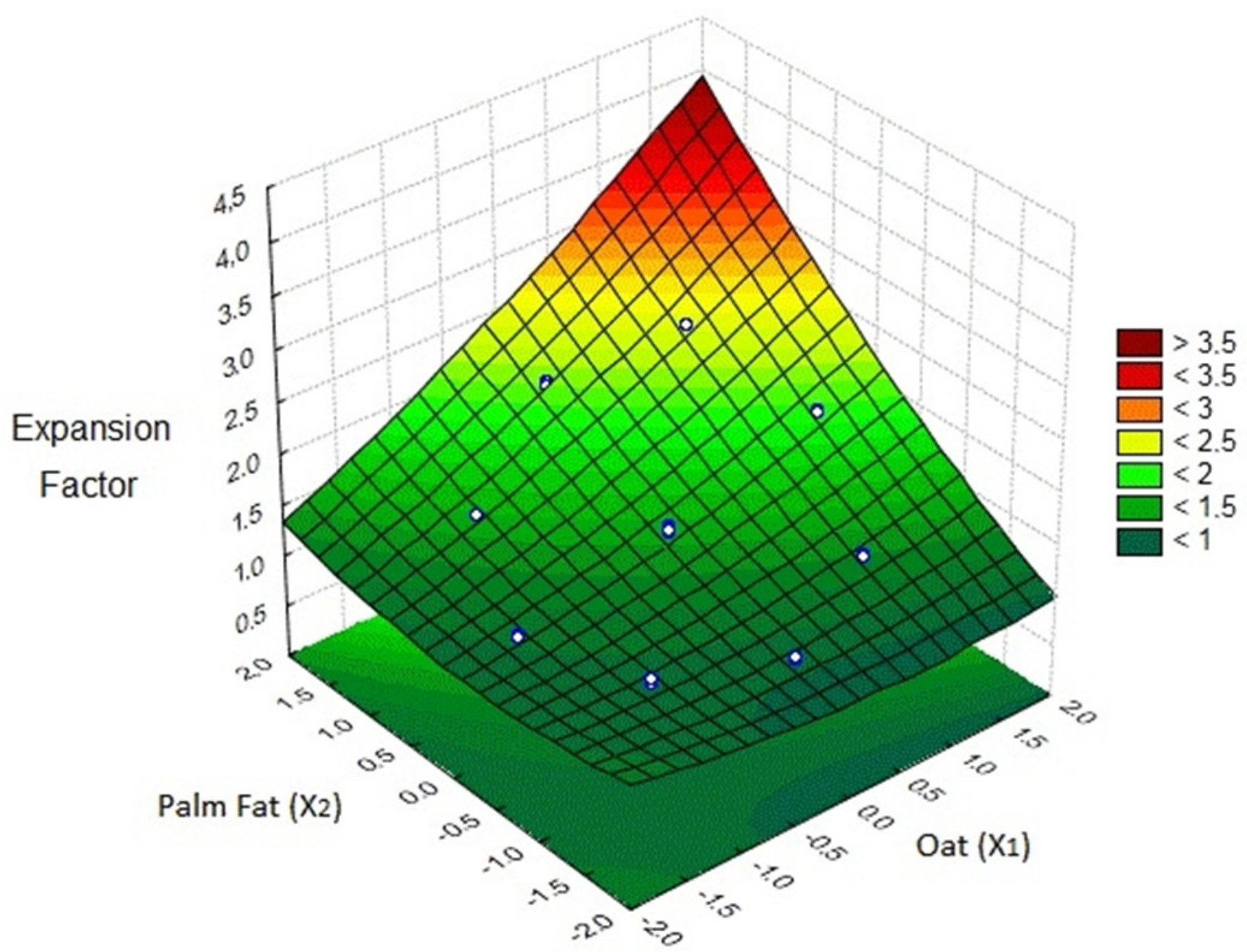

Figure 1. Effect of the oat and palm fat content in the expansion index of cookie biscuits.

Table 4. Regression Models for specific volume (SV), mean expansion index $(\mathrm{MEI})$, lighting $\left(\mathrm{L}^{\star}\right)$, red intensity $\left(\mathrm{a}^{\star}\right)$, general appearance $(\mathrm{GA})$, texture (T), and taste (TA) of the formulations elaborated.

\begin{tabular}{ll}
\hline Response & \multicolumn{1}{c}{ Model $^{\mathrm{a}}$} \\
\hline $\mathrm{MEI}$ & $1.471+0.298 \mathrm{X}_{1}+0.039 \mathrm{X}_{1}^{2}+0.387 \mathrm{X}_{2}+0.057 \mathrm{X}_{2}^{2}+0.177 \mathrm{X}_{1} \cdot \mathrm{X}_{2}$ \\
$\mathrm{SV}$ & $1.557+0.120 \mathrm{X}_{1}+0.066 \mathrm{X}_{1}^{2}+0.063 \mathrm{X}_{2}^{2}+0.043 \mathrm{X}_{1} \cdot \mathrm{X}_{2}$ \\
$\mathrm{~L}^{*}$ & $66.894-6.901 \mathrm{X}_{1}$ \\
$\mathrm{a}^{*}$ & $5.056+2.440 \mathrm{X}_{1}$ \\
$\mathrm{GA}$ & $7.636-4.5953 \mathrm{X}_{1}^{2}-4.5953 \mathrm{X}_{2}^{2}-6.2977 \mathrm{X}_{1} \cdot \mathrm{X}_{2}$ \\
$\mathrm{~T}$ & $7.9772-2.7255 \mathrm{X}_{1}-4.8182 \mathrm{X}_{1}^{2}+1.5484 \mathrm{X}_{2}-3.4844 \mathrm{X}_{2}^{2}-2.9440 \mathrm{X}_{1} \cdot \mathrm{X}_{2}$ \\
TA & $6.9879-3.6883 \mathrm{X}_{1}^{2}-4.9379 \mathrm{X}_{1} \cdot \mathrm{X}_{2}$ \\
\hline $\mathrm{X}_{1}=$ Oat; $\mathrm{X}_{2}=$ Palm fat.
\end{tabular}

intensity and perception. Oat, according to Zhou et al. (2000), has phenolic compounds which are responsible for the characteristics of taste and smell.

Lee et al. (2009) used different concentrations of oat hydrocolloids in the formulation of biscuits and found significant differences in taste and smell. Cerpovicz and Baldree (2002) used fat substitute in chocolate biscuits and also found differences in taste by comparing the biscuits developed with the control biscuits.
The color of the biscuits is one of the first characteristics observed by the consumer, influencing the acceptance of the product (SIMAS et al., 2009). It can be changed due to the ingredients used in the formulation and the time and temperature of the baking causing Mailard reaction and caramelization (GUTKOSKI et al., 2007).

In the adapted regression model (Table 4), only the linear oat effect influenced negatively on lighting $\left(\mathrm{L}^{*}\right)$ and red intensity $\left(\mathrm{a}^{*}\right)$. The increase in the oat concentration reduced the $\mathrm{L}^{*}$ value proportionally and increased the $\mathrm{a}^{*}$ value.

Therefore, it can be said that there was a greater darkening of the biscuits after oat addition, probably due to larger protein content. Similar results were found by Artz et al. (1990), who found that the biscuits without addition of fiber had lighter color.

In the adapted regression model, the linear and quadratic effects of oat and palm fat influenced significantly the texture, evaluated by sensory hardness (Table 4 ). The formulations with low levels of palm fat and high contents of oat obtained the lowest scores for the texture parameter. Lee and Inglett (2006) state that some of the most important roles of fat in baked products is to provide softness and improve the texture. 
According to Simas et al. (2009), the addition of sources of fibers to bakery products increase the capacity of binding the water, which influences the products' texture.

Figure 2 presents the diagram of surface correspondent to the model adapted that determines the texture variation because of oat and palm fat concentrations used in the formulations.

In the adapted regression model, the quadratic effects of oat and palm fat influenced significantly $(p<0.05)$ the general appearance of the biscuit (Table 4). Figure 3 shows the diagram of the oat and palm fat effect on the general appearance of the biscuit.

The results of the general appearance (Figure 3), concerning the physical analysis, showed that the formulations which presented very light colors (A9G8 and A0G15) and those that presented very dark color (A51G22 and A60G15) had lower scores for general appearance. Similarly, the formulations with high expansion index (A51G22 and A30G25) and the formulations with low expansion index (A9G8 and A30G15) also obtained lower scores for general appearance.
The criterion used for the selection of the best formulations was the average values obtained for color (lighting and red intensity) and expansion index and the highest scores obtained for general appearance and texture. The formulations selected were A51G8, A9G22, and A30G15.

\subsection{Physicochemical analysis of the formulations selected}

The results of the chemical composition of the three formulations selected of the biscuits added with oat and palm fat are shown in Table 5.

The protein and total food fiber contents of the biscuits increased with the increase in the oat content in the formulations. The lowest content of fiber and the lowest content of protein were found in the formulation with lower concentration of oat (A9G22). This behavior is in accordance with the findings of Gutkoski et al. (2007), who observed that the addition of oat flakes and $\beta$-glucans concentration increased the contents of fiber and protein in the cookie biscuit.

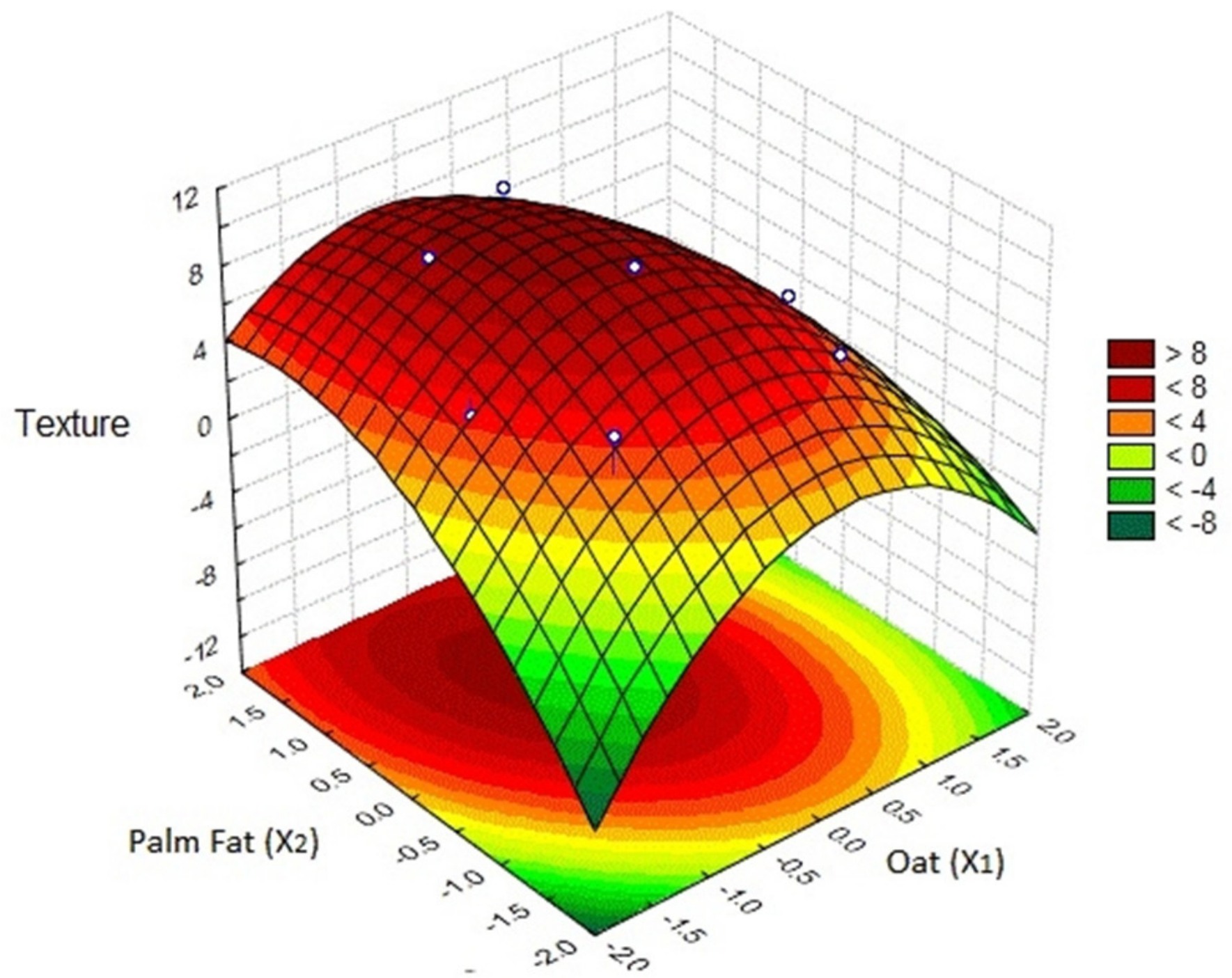

Figure 2. Oat and palm fat content effect in the cookie biscuits texture. 


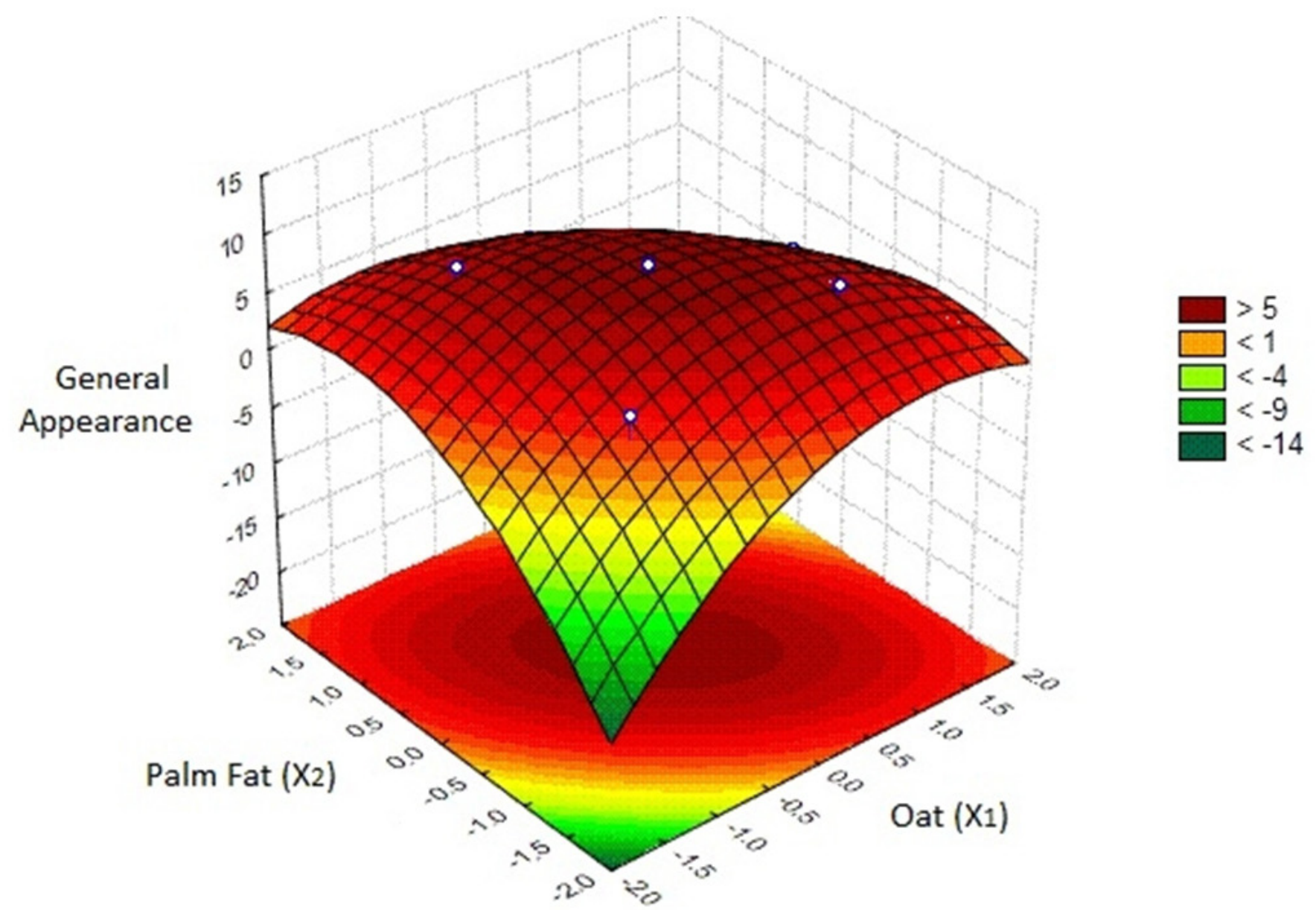

Figure 3. Effect of oat and palm fat content on the cookie biscuits general appearance.

Table 5. Physicochemical analyses and total caloric value (TCV) of the three formulations selected of the biscuits added with oat and palm fat.

\begin{tabular}{|c|c|c|c|}
\hline Physico-chemical parameter & A51G8 & A9G22 & A30G15 \\
\hline Lipids (g.100 g $\left.{ }^{-1}\right)$ & $14.51 \pm 0.71^{\mathrm{c}}$ & $26.45 \pm 0.99^{\mathrm{a}}$ & $21.87 \pm 0.67^{b}$ \\
\hline Total food fiber (g.100 g-1) & $3.36 \pm 0.40^{\mathrm{a}}$ & $2.17 \pm 0.05^{\mathrm{b}}$ & $2.52 \pm 0.05^{\mathrm{a} . \mathrm{b}}$ \\
\hline Ashes $\left(\mathrm{g} .100 \mathrm{~g}^{-1}\right)$ & $2.27 \pm 0.04^{\mathrm{a}}$ & $2.24 \pm 0.09^{\mathrm{a}}$ & $2.59 \pm 0.14^{\mathrm{a}}$ \\
\hline Humidity (g.100 g $\left.\mathrm{g}^{-1}\right)$ & $4.99 \pm 0.12^{\mathrm{a}}$ & $4.25 \pm 0.02^{\mathrm{b}}$ & $5.27 \pm 0.02^{\mathrm{a}}$ \\
\hline Protein $\left(\mathrm{g} .100 \mathrm{~g}^{-1}\right)$ & $7.99 \pm 0.25^{\mathrm{a}}$ & $5.96 \pm 0.08^{c}$ & $6.75 \pm 0.04^{\mathrm{b}}$ \\
\hline Carbohydrates (g.100 g ${ }^{-1}$ ) & $66.88 \pm 0.10^{\mathrm{a}}$ & $58.93 \pm 1.03^{\mathrm{b}}$ & $61.00 \pm 0.46^{\mathrm{b}}$ \\
\hline TCV (kcal.100 g $\left.{ }^{-1}\right)$ & $430.07 \pm 5.76^{c}$ & $497.61 \pm 4.46^{\mathrm{a}}$ & $467.83 \pm 4.07^{\mathrm{b}}$ \\
\hline
\end{tabular}

Averages followed by the same letter in the line are not statistically different by the Tukey test at $5 \%$ probability.

The content of lipids and the TCV (total caloricific value), are related to the quantity of fat added, and they have little influence on oat concentration. Thus, the content of lipids and the TCV increased as with the increase in the concentration of palm fat. The TCV obtained is similar to that found in commercial biscuits elaborated with high content of food fiber, which have an average of $460 \mathrm{kcal} .100 \mathrm{~g}^{-1}$ (PEREZ; GERMANI, 2007).

The trans fatty acid (TFA) contents of the formulations selected were lower than $0.01 \mathrm{~g} \cdot 100 \mathrm{~g}^{-1}$, which is due to the use of palm fat replaced with hydrogenated vegetable fat. Dias and Gonçalves (2009) evaluated different brands of water and salt biscuits and found TFA between $0 \mathrm{~g} .100 \mathrm{~g}^{-1}$ and $4.0 \mathrm{~g} .100 \mathrm{~g}^{-1}$. Aued-Pimentel et al. (2003) analyzed 26 samples of four different kinds of sweet and salt biscuits and found similar contents of TFA in most samples. The average of TFA in the analyzed biscuit was 3.0 g. $100 \mathrm{~g}^{-1}$. Dias and Gonçalves (2009), investigating the contribution of foods with high contents of TFA, verified that their intake exceeds the Health World Organization's daily recommendation; this result is worrisome since several metabolic effects have been associated to high consumption of these fatty acids. Furthermore, TFA were included among the dietary lipids that act as risk factors for coronary artery disease (LICHTENSTEIN, 1993). 
The formulations A51G8, A9G22, and A30G15 had calcium concentration $385.21 \pm 0.14 \mathrm{mg} .100 \mathrm{~g} \mathrm{~g}^{-1}, 416.55 \pm 0.21 \mathrm{mg} .100 \mathrm{~g} \mathrm{~g}^{-1}$ and $349.68 \pm 0.17 \mathrm{mg} .100 \mathrm{~g}^{-1}$, respectively. The base formulation of the biscuit, without addition of L-leucine and calcium phosphate, presented $33.43 \pm 0.25 \mathrm{mg} .100 \mathrm{~g}^{-1}$ calcium, showing that the addition of calcium increased by around 10 times the concentration of this mineral in the product. DRI (Dietary Reference Intake) for people over 51 years old indicates that the daily consumption of calcium must be $1200 \mathrm{mg} \cdot \mathrm{d}^{-1}$ (INSTITUTE..., 1997, 2005). According to the Ordinance $n^{\circ} 29$ of ANVISA (BRASIL, 1998), a solid food can be considered high or rich content of vitamins and minerals since $100 \mathrm{~g}$ of the product ready for consumption provide at least $30 \%$ of DRI reference. Therefore, the formulations A51GP8 and A9GP22 had values over $30 \%$ DRI, which is more than $360 \mathrm{mg} \cdot 100 \mathrm{~g}^{-1}$, and thus it is considered a food rich in calcium. Calcium is an essential mineral for normal muscle function because it is released when muscle fibers are stimulated. Calcium is needed for muscle contraction (WILMORE; COSTILL, 2001). For individuals whose consumption of food containing calcium is limited, fortified foods are an alternative to achieve adequate intake (BRYANT; CADOGAN; WEAVER, 1999).

The base formulation (without addition of L-leucine and calcium phosphate) and the central point formulation (A30G15) had $227.52 \pm 0,13 \mathrm{mg} \cdot 100 \mathrm{~g}^{-1}$ and $933.84 \pm 0,01 \mathrm{mg} \cdot 100 \mathrm{~g}^{-1}$ leucine, respectively. DRI of leucine for people over 51 years old, indicates that the consumption must be $42 \mathrm{mg}$. (kg body weight $)^{-1}$ i.e., a person who weighs $60 \mathrm{~kg}$ should eat $2520 \mathrm{mg} . \mathrm{d}^{-1}$ leucine. The $100 \mathrm{~g}$ consumption of the biscuit developed in the present study represents more than $30 \%$ of DRI for a person weighing $60 \mathrm{~kg}$.

According to Silva et al. (2006) and Roberts (1995) malnutrition is a serious factor for sarcopenia since the majority of the elderly do not consume enough protein according to the recommended daily intake of protein. Houston et al. (2008) evaluated a group of elderly in order to associate protein diet and muscle mass loss and concluded that a diet with proteins can be a modifiable risk factor to reduce the risk of sarcopenia. According to Zanchi, Nicastro and Lancha Junior (2008), supplementation with leucine induces the inhibition of proteolysis in the skeletal muscle, reducing the muscle mass loss.

Rieu et al. (2006) demonstrated that supplementation with leucine improves the muscle protein synthesis in the elderly. These authors argue that the relevance of their study is the fact that supplementation of leucine occurred after the intake of a full meal containing proteins, carbohydrates, and lipids, suggesting that this may represent an effective nutritional strategy to limit the loss of muscle protein that normally accompanies aging. The high levels of amino acid L-leucine in the biscuit developed in the present study make it an important ingredient for the prevention of sarcopenia in the elderly.

After 12 months of study on elderly health, a group of researchers published recommendations for nutritional management in sarcopenia. They suggest that supplementation of amino acids, especially high leucine doses, is effective in building and maintaining muscle mass in elderly (MORLEY et al., 2010). Thus, the option of a food rich in this amino acid and with
Table 6. Sensory evaluation performed by the target group of the three formulations selected of the biscuits added with oat and palm fat added.

\begin{tabular}{lccr}
\hline \multicolumn{1}{c}{ Parameter } & \multicolumn{1}{c}{ A51G8 } & \multicolumn{1}{c}{ A9G22 } & \multicolumn{1}{c}{ A30G15 } \\
\hline Acceptance & $4.09 \pm 0.84^{\mathrm{a}}$ & $4.54 \pm 0.69^{\mathrm{b}}$ & $4.55 \pm 0.56^{\mathrm{b}}$ \\
Texture & $3.6 \pm 1.45^{\mathrm{a}}$ & $4.43 \pm 0.97^{\mathrm{b}}$ & $4.3 \pm 0.88^{\mathrm{b}}$ \\
Global appearance & $4.2 \pm 1.13^{\mathrm{a}}$ & $4.67 \pm 0.66^{\mathrm{a}}$ & $4.7 \pm 0.53^{\mathrm{a}}$ \\
Color & $4.23 \pm 0.9^{\mathrm{a}}$ & $4.57 \pm 0.68^{\mathrm{a}}$ & $4.57 \pm 0.82^{\mathrm{a}}$ \\
Smell & $4.1 \pm 1.18^{\mathrm{a}}$ & $4.5 \pm 1.07^{\mathrm{a}}$ & $4.53 \pm 0.78^{\mathrm{a}}$ \\
Taste & $4.3 \pm 1.02^{\mathrm{a}}$ & $4.53 \pm 1.04^{\mathrm{a}}$ & $4.63 \pm 0.85^{\mathrm{a}}$ \\
\hline
\end{tabular}

Averages followed by the same letter in the line are not statistically different by the Tukey test at $5 \%$ probability.

characteristics suitable for the elderly becomes an alternative for the management of sarcopenia.

\subsection{Sensory evaluation of the formulations selected performed by the target group}

Table 6 presents the results of the sensory evaluation performed by the target group of the three formulations selected of biscuits added with oat and palm fat.

The affective test performed by the target group showed that the global acceptance was among $4.09 \pm 0.84$ (A51G8) and $4.55 \pm 0.56$ (A30G15), around $81.9 \%$ and $91 \%$ acceptance, respectively, showing high affective status and confirming that the product developed was accepted.

In the statistical evaluation of the sensory characteristics texture, color, smell, taste, and global appearance, it was verified that only texture had significant difference between the formulations evaluated $(\mathrm{p}<0.05)$ and that it influenced the global acceptance of the biscuits. The acceptance of formulation A51G8 was statistically lower than that of formulations A9G22 and A30G15. The largest concentration of oat and the lower concentration of palm fat may have influenced negatively on the A51G8 formulation texture, and this result influenced the global acceptance of the biscuit by the elderly.

The importance of texture in the biscuit acceptance by the consumer is increasingly known. Changes in the ingredients and processing may cause variations in this characteristic (ZOULIAS; OREOPOULOU; TZIA, 2002). Perception ability of different texture characteristics of food and chewing efficiency are important factors that must be considered in old age. The industry of food needs to elaborate products with strong flavor, but with adequate texture as well, in order to increase the acceptance of the food (FILLION; KILCAST, 2001).

\section{Conclusion}

Oat and palm fat influenced the physical and sensorial characteristics of the biscuits elaborated. These parameters allowed the selection of formulations A51G8 (51\% oat and 8\% palm fat), A9G22 (9\% oat and 22\% palm fat), and A30G15 (30\% oat and $15 \%$ palm fat).

The addition of calcium enabled the elaboration of a food rich in calcium, i.e., $30 \%$ of the DRI. Furthermore, the use of oatmeal contributed to the elaboration of a cookie with the 
presence of fibers. The biscuit developed may be considered an important food for the prevention of sarcopenia in the elderly since the consumption of $100 \mathrm{~g}$ of this biscuit represents more than $30 \%$ of DRI of L-leucine amino acid.

The sensory analysis of the formulations selected performed by the elderly group showed high acceptance, presenting potential for the inclusion of this product in the market. The sensory acceptance of the samples was influenced by texture only $(\mathrm{p}<0.05)$.

\section{Aknowledgements}

The authors are grateful to Company Prozyn Biosolutions, Companhia Brasileira de Moagem, and to the Regional Center of Studies and Activities for the Elderly of the University of Passo Fundo (CREATI-UPF).

\section{References}

ALONSO, N.; HIRS, C. H. W. Automation of sample application in amino acid analysers. Analytical Biochemistry, v. 23, n. 2, p. 272-288, 1968. http://dx.doi.org/10.1016/0003-2697(68)90359-X

ALVES, L. C.; LEITE, I. C.; MACHADO, C. J. Conceituando e mensurando a incapacidade funcional da população idosa: uma revisão de literatura. Ciência \& Saúde Coletiva, v. 13, n. 4, p. 1199-1207, 2008. PMid:18813619. http://dx.doi.org/10.1590/ S1413-81232008000400016

AMERICAN ASSOCIATION OF CEREAL CHEMISTS - AACC. Approved methods of the American Association of Cereal Chemists. 9th ed. Saint Paul: AACC, 1995. v. 2.

AMERICAN OIL CHEMISTS' SOCIETY - AOCS. Official methods and recommended practices of the American Oil Chemist's Society. Champaign: AOCS, 2002.

ASSOCIATION OF OFFICIAL ANALYTICAL CHEMISTRY - AOAC. Official methods of analysis of the Association of Official Analytical Chemistry. 18th ed. Washington: AOAC, 2005.

ARTZ, W. E. et al. Incorporation of corn fiber into sugar snap cookies. Cereal Chemists, v. 67, n. 3, p. 303-305, 1990.

AUED-PIMENTEL, S. et al. Ácidos graxos trans versus saturados em biscoitos. Revista do Instituto Adolfo Lutz, v. 62, n. 2, p. 131-137, 2003.

BARROS NETO, B.; SCARMINIO, I. S.; BRUNS, R. E. Planejamento e otimização de experimentos. 2. ed. Campinas: Editora da Unicamp, 1995. PMid:7584822.

BATH, D. E.; SHELKE, K.; HOSENEY, R. C. Fat replacers in high-ratio layer cakes. Cereal Foods World, v. 37, n. 7, p. 495-500, 1992.

BELLO, J. Los alimentos funcionales o nutraceuticos: nueva gama de productos em la indústria alimentaria. Alimentaria, n. 265, p. 25-30, 1995.

BORST, S. E. Interventions for sarcopenia and muscle weakness in older people. Age and Ageing, v. 33, n. 6, p. 548-555, 2004. PMid:15385272. http://dx.doi.org/10.1093/ageing/afh201

BOX, G. P.; DRAPER, N. R. Empirical Model-Building and Response Surfaces. New York: J. Wiley; Sons, 1987.

BRASIL. Ministério da Saúde. Portaria n² 29, de 13 de janeiro de 1998. Regulamento técnico referente a alimentos para fins especiais. Diário Oficial da República Federativa do Brasil Brasília, DF, 15 jan. 1998. Seção 1.
BRASIL. Ministério da Saúde. Agência Nacional de Vigilância Sanitária. Resolução - RDC n 360, de 23 de dezembro de 2003. Regulamento técnico sobre rotulagem nutricional de alimentos embalados. Diário Oficial da República Federativa do Brasil, Brasília, DF, 26 dez. 2003. Seção 1, p. 33.

BRYANT, R. J.; CADOGAN J.; WEAVER C. M. The new dietary reference intakes for calcium: implications for osteoporosis. Journal of the American. College of Nutrition, v. 18, n. 5, p. 406-412, 1999.

BUCCI, M. et al. Efeitos do treinamento concomitante hipertrofia e endurance no músculo esquelético. Revista Brasileira Ciência e Movimento, v. 13, n. 1, p. 17-28, 2005.

CANDIDO, L. M. B.; CAMPOS, A. M. Alimentos funcionais. Uma revisão. Boletim da SBCTA, v. 29, n. 2, p. 193- 203, 2005.

CERPOVICZ, R. W.; BALDREE, K. A. Moisture retention and consumer acceptability of chocolate bar cookies prepared with okra gum as a fat ingredient substitute. Journal of the American Dietetic Association, v. 102, n. 9, p. 1301-1303, 2002. http://dx.doi. org/10.1016/S0002-8223(02)90287-7

COMBARET, L. et al. A leucine-supplemented diet restores the defective postprandial inhibition of proteasome-dependent proteolysis in aged rat skeletal muscle. Journal of Physiology, v. 569, n. 2, p. 489-499, 2005. PMid:16195315 PMCid:1464228. http://dx.doi.org/10.1113/jphysiol.2005.098004

DARDEVET, D. et al. Leucine: a key amino acid in ageing-associated sarcopenia? Nutrition Research Reviews, v. 16, n. 1, p. 61-70, 2003. PMid:19079937. http://dx.doi.org/10.1079/NRR200252

DARDEVET, D. et al. Postprandial stimulation of muscle protein synthesis in old rats can be restored by a leucine supplemented meal. Journal of Nutrition, v. 132, n. 1, p. 95-100, 2002. PMid:11773514.

DIAS, J. R.; GONÇALVES, E. C. B. A. Avaliação do consumo e análise da rotulagem nutricional de alimentos com alto teor de ácidos graxos trans. Ciência e Tecnologia de Alimentos, v. 29 , n. 1 , p. 177-182, 2009. http://dx.doi.org/10.1590/S010120612009000100027

EL-DASH, A. A.; CAMARGO C. R. O. Fundamentos da tecnologia de panificação. São Paulo: Secretaria da Indústria, Comércio e Tecnologia, 1982.

ELMER, P. Analytical Methods for Atomic Absorption Spectrophotometry. Norwalk, 1982.

FARIA, E. V.; YOTSUYANAGI, K. Técnicas de análise sensorial. Campinas: ITAL/LAFISE, 2002.

FILLION, L.; KILCAST, D. Food texture and eating difficulties in the elderly. Food Industry Journal, v. 4, n. 1, p. 27-33, 2001.

GARCIA, E. S. S.; SAINTRAIN, M. V. L. Perfil epidemiológico de uma população idosa atendida pelo programa saúde da família. Revista Enfermagem UERJ, v. 17, n. 1, p. 18-23, 2009.

GUTKOSKI, L. C. et al. Biscoitos de aveia tipo cookie enriquecidos com concentrado de $\beta$-glicanas. Brazilian Journal of Food Technology, v. 10, n. 2, p. 104-110, 2007.

GUTKOSKI, L. C. et al. Influência dos teores de aveia e de gordura nas características tecnológicas e funcionais de bolos. Ciência e Tecnologia de Alimentos, v. 29, n. 2, p. 254-261, 2009. http://dx.doi. org/10.1590/S0101-20612009000200003

HOUSTON, D. K. et al. Dietary protein intake is associated with lean mass change in older, community-dwelling adults: the health, aging, and body composition (Health ABC) Study1-3. American Journal of Clinical Nutrition, v. 87, p. 150-155, 2008. PMid:18175749.

INSTITUTE OF MEDICINE - IOM. Dietary reference intakes for calcium, phosphorus, magnesium, vitamin D and fluoride. Washington: National Academy Press, 1997. 
INSTITUTE OF MEDICINE - IOM. Dietary reference intakes for energy, carbohydrate, fiber, fat, fatty acids, cholesterol, protein, and amino acids. Washington: National Academy Press, 2005.

LEE, S. et al. Flavor and texture attributes of foods containing b-glucanrich hydrocolloids from oats. Food Science and Technology, v. 42, n. 1, p. 350-357, 2009.

LEE, S.; INGLETT, G. E. Rheological and physical evaluation of jetcooked oat bran in low calorie cookies. International Journal of Food Science and Technology, v. 41, n. 5, p. 553-559, 2006. http:// dx.doi.org/10.1111/j.1365-2621.2005.01105.x

LICHTENSTEIN, A. Trans fatty acids, blood lipids and cardiovascular risk: where do we stand? Nutrition Reviews, v. 51, n. 11 , p. $340-343$, 1993. PMid:8108036. http://dx.doi. org/10.1111/j.1753-4887.1993.tb03762.x

LIST, G. R. Decreasing trans and saturated fatty acid content in food oils. Food Technology, v. 58, n.1, p. 23-31, 2004.

MORLEY, J. E. et al. Nutritional recommendations for the management of sarcopenia. Journal of the American Medical Directors Association, v. 11, n. 6, p. 391-396, 2010. PMid:20627179. http:// dx.doi.org/10.1016/j.jamda.2010.04.014

MURALIDHAR, R. V. et al. A response surface approach for the comparison of lipase production by Candida cylindracea using two different carbon sources. Biochemical Engineering Journal, v. 9, n. 1, p. 17-23, 2001. http://dx.doi.org/10.1016/S1369703X(01)00117-6

NAIR, K. S.; SCHWARTZ, R. G.; WELLE, S. Leucine as a regulator of whole body and skeletal muscle protein metabolism in humans. American Journal of Physiology-Endocrinology and Metabolism, v. 263, n. 5, p. 928-934, 1992.

PEREZ, P. M. P.; GERMANI, R. Elaboração de biscoitos tipo salgado, com alto teor de fibra alimentar, utilizando farinha de berinjela (Solanum melongena, L.). Ciência e Tecnologia de Alimentos, v. 27, n. 1, p. 186-192, 2007. http://dx.doi.org/10.1590/S010120612007000100033

RASCO, B. A. et al. Baking properties of bread and cookies incorporating distillers' or brewer's grain from wheat or barley. Journal of Food Science, v. 55, n. 2, p. 424-429, 1990. http://dx.doi. org/10.1111/j.1365-2621.1990.tb06778.x

RIEU, I. et al. Leucine supplementation improves muscle protein synthesis in elderly men independently of hyperaminoacidaemia. Journal of Physiology, v. 575, n. 1, p. 305-315, 2006. PMid:16777941 PMCid:1819434. http://dx.doi.org/10.1113/jphysiol.2006.110742

RIEU, I. et al. Increased availability of leucine with leucine-rich whey proteins improves postprandial muscle protein synthesis in aging rats. Nutrition, v. 12, n. 7, p. 433-450, 2007.

ROBERTS, S. B. Effects of aging on energy requirements and the control of food intake in men. The Journals of Gerontology. Series A, Biological Sciences and Medical Sciences, v. 50, p. 101-106, 1995. PMid:7493200.
SILVA, M. R.; SILVA, M. A. A. P.; CHANG, Y. K. Utilização da farinha de jatobá (Hymenaea stigonocarpa Mart.) na elaboração de biscoitos tipo cookie e avaliação de aceitação por testes sensoriais afetivos univariados e multivariados. Ciência e Tecnologia de Alimentos, v. 18, n. 1, p. 25-34, 1998. http://dx.doi.org/10.1590/ S0101-20611998000100007

SILVA, T. A. A. et al. Sarcopenia associada ao envelhecimento: aspectos etiológicos e opções terapêuticas. Revista Brasileira de Reumatologia, v. 46, n. 6, p. 391-397, 2006. http://dx.doi. org/10.1590/S0482-50042006000600006

SIMAS, K. N. et al. Effect of king palm (Archontophoenix alexandrae) flour incorporation on physicochemical and textural characteristics of gluten-free cookies. International Journal of Food Science and Technology, v. 44, n. 3, p. 531-538, 2009. http://dx.doi.org/10.1111/ j.1365-2621.2008.01840.x

SPACKMAN, D. H.; STEIN, W. H.; MOORE, S. Automatic recording apparatus for use in the chromatography of aminoacids. Analytical Chemistry, v. 30, n. 7, p. 1190-1206, 1958. http://dx.doi.org/10.1021/ ac60139a006

VENTRUCCI, G. et al. Effects of a leucine-rich diet on body composition during nutritional recovery in rats. Nutrition, v. 20, n. 2, p. 213-217, 2004. PMid:14962689. http://dx.doi.org/10.1016/j. nut.2003.10.014

WENZ, T. et al. Increased muscle PGC-1 expression protects from sarcopenia and metabolic disease during aging. Proceedings of the National Academy of Sciences of the United States of America, v. 106, n. 48, p. 20405-20410, 2009. PMid:19918075 PMCid:2787152. http://dx.doi.org/10.1073/pnas.0911570106

WILMORE, J. H.; COSTILL, D. L. Fisiologia do esporte e do exercício. 2. ed. São Paulo: Manole, 2001.

ZANCHI, N. E.; NICASTRO, H.; LANCHA JUNIOR, A. H. Potential antiproteolytic effects of L-leucine: observations of in vitro and in vivo studies. Nutrition \& Metabolism, v. 5, n. 1, p. 20, 2008. PMid:18637185 PMCid:2488337. http://dx.doi.org/10.1186/17437075-5-20

ZIEGLER, F. F.; SGARBIERI, V. C. Caracterização químico-nutricional de um isolado protéico de soro de leite, um hidrolisado de colágeno bovino e misturas dos dois produtos. Revista de Nutrição, v. 22, n. 1, p. 61-70, 2009. http://dx.doi.org/10.1590/S141552732009000100006

ZOULIAS, E. I.; OREOPOULOU, V.; TZIA, C. Textural properties of low-fat cookies containing carbohydrate- or protein-based fat replacers. Journal of Food Engineering, v. 55, n. 4, p. 337-342, 2002. http://dx.doi.org/10.1016/S0260-8774(02)00111-5

ZHOU, M. et al. Contribution of volatiles to the flavour of oatmeal. Journal of the Science of Food and Agriculture, v. 80, n. 2, p. 247-254, 2000. http://dx.doi.org/10.1002/(SICI)10970010(20000115)80:2<247::AID-JSFA525>3.0.CO;2-0 